( $)$ institute of development studies

Working Paper

Volume 2021 Number 551

\title{
Demanding Power: Contentious Politics and Electricity in Pakistan
}

Umair Javed, with Aiza Hussain and Hassan Aziz June 2021 
The Institute of Development Studies (IDS) delivers world-class research, learning and teaching that transforms the knowledge, action and leadership needed for more equitable and sustainable development globally.

Action for Empowerment and Accountability (A4EA) is an international research programme which explores how social and political action can contribute to empowerment and accountability in fragile, conflict, and violent settings, with a particular focus on Egypt, Mozambique, Myanmar, Nigeria, and Pakistan.

Led by the Institute of Development Studies, A4EA is being implemented by a consortium which includes: the Accountability Research Center, the Collective for Social Science Research, the Institute of Development and Economic Alternatives, Itad, Oxfam GB, and the Partnership for African Social and Governance Research.

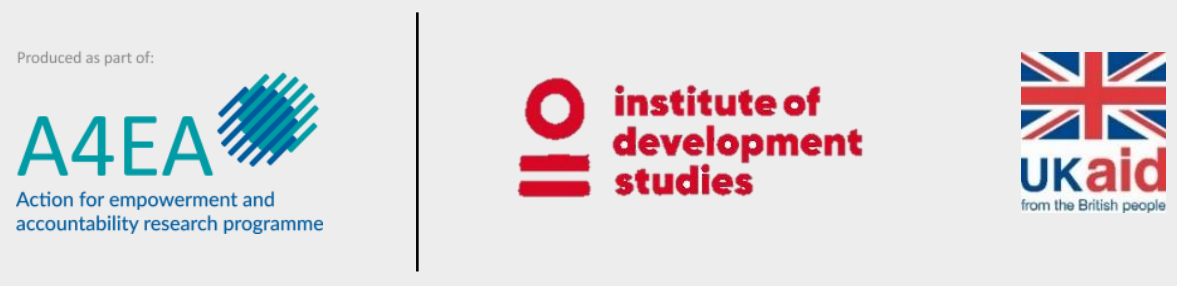

(C) Institute of Development Studies 2021

Working Paper Volume 2021 Number 551

Demanding Power: Contentious Politics and Electricity in Pakistan

Umair Javed, with Aiza Hussain and Hassan Aziz

June 2021

First published by the Institute of Development Studies in June 2021

ISSN: 2040-0209 ISBN: 978-1-78118-808-8

DOI: $10.19088 / I D S .2021 .047$

Suggested citation: Javed, U. with Hussain, A. and Aziz, H. (2021) Demanding Power: Contentious Politics and Electricity in Pakistan, IDS Working Paper 551, Brighton: Institute of Development Studies, DOI:

10.19088/IDS.2021.047

A catalogue record for this publication is available from the British Library.

This paper is funded with UK aid from the UK government (Foreign, Commonwealth \& Development Office FCDO, formerly DFID). The opinions are the authors and do not necessarily reflect the views or policies of IDS or the UK government.

This is an Open Access paper distributed under the terms
Attribution 4.0 International licence (CC BY), which permition,
distribution, and reproduction in any medium, provided the original authors and
modifications or adaptations are indicated.
Available from:
Institute of Development Studies, Library Road
Brighton, BN1 9RE, United Kingdom
+44 (0)1273 915637
ids.ac.uk
IDS is a charitable company limited by guarantee and registered in England
Charity Registration Number 306371
Charitable Company Number 877338


Working Paper

Volume 2021 Number 551

\section{Demanding Power: Contentious Politics and Electricity in Pakistan}

Umair Javed, with Aiza Hussain and Hassan Aziz June 2021 


\title{
Demanding Power: Contentious Politics and Electricity in Pakistan
}

\author{
Umair Javed, with Aiza Hussain and Hassan Aziz
}

June 2021

\section{Summary}

This paper explores Pakistan's electricity supply crisis that lasted from 2007 to 2015 , and the ensuing contention that shaped public discourse and political events in the country. During this period, which witnessed electricity outages of up to 14 hours per day, 456 incidents of contention took place, with just under 20 per cent escalating into some form of violence. Electricity became the number one political issue in the country and was integral in shaping the outcomes of the 2013 General Election. Following the election, public authorities undertook extensive investment to expand capacity and ensure consistency in supply while evading questions about affordability and sustainability.

On the surface, this appears to be a case of extensive protest working towards shaping state responsiveness. And it is true that the state now sees supply as a non-negotiable aspect in the social contract with citizens. However, a range of factors contributed to the chronology and the selective, generation-focused nature of this response: the cross-sectional socioeconomic and organisational nature of those impacted by the crisis; the increasing cost imposed on public authorities by extensive protests; the nature of the political opportunity structure available for opposition political parties to capitalise on the crisis; and the pressures imposed by key civil society actors, most dominantly, the private news media. On the other hand, citizen inclusion and participation in decision-making, and issues of affordability and sustainability, which impact vulnerable and disempowered groups the most, remain absent from the political and policy conversation around energy. This suggests that while protests were useful in generating a short-term response, their long-term legacy in empowerment related outcomes is less visible.

\section{Keywords}

Electricity; protests; Pakistan; load-shedding; riots. 


\section{Authors}

Umair Javed is Assistant Professor of Politics and Sociology at the Lahore University of Management Sciences (LUMS) and a Visiting Research Fellow at the Institute of Development and Economic Alternatives (IDEAS).

Aiza Hussain, Institute of Development and Economic Alternatives (IDEAS). Hassan Aziz, Lahore University of Management Sciences (LUMS). 


\section{Contents}

Acknowledgements

1. Introduction

1.1 Background and motivations

1.2 The Demanding Power project

1.3 Country context: the political economy of energy in everyday life in Pakistan

1.3.1 Electricity in everyday lives

1.3.2 Electricity supply and system

1.3.3 Electricity subsidies, financial viability, and the $2007-15$ crisis

1.3.4 Actors and interests in the electricity sector

2. Approach and methodology

2.1 Pakistan case study methodology

2.2 The Demanding Power Pakistan events catalogue

3. Political fragility and the escalation of energy struggles

4. Energy protests and accountability for energy provisioning

5. Energy struggles as a source of citizen empowerment

6. Transnational actors and the contentious political economy of energy

7. Conclusions: Did energy struggles empower people to hold their rulers to account in Pakistan? 
7.2 The contingent possibility of accountability after contention

7.3 The (im)possibility of empowerment

Annexe 1

References

Figures

Figure A1 Protest distribution by month

Figure A2 Occupational profile of protestors 48

Figure A3 Frequency of violence in protests 


\section{Acknowledgements}

The authors thank Naomi Hossain, John Gaventa, Neil McCulloch, and the rest of the Demanding Power team for their framework, empirical insights, and advice throughout. Special gratitude is in order to the respondents in Lahore, Kamalia, Islamabad, and elsewhere without whom this research would not have been possible.

This research has been funded by UK Aid (Foreign, Commonwealth \& Development Office - FCDO, formerly DFID) under the Action for Empowerment and Accountability (A4EA) programme. This paper was part of a larger project called Demanding Power, with case studies of struggles on energy and fuel access in Pakistan, Nigeria, and Mozambique. The views expressed in this publication do not necessarily reflect the official policies of our funder. 


\section{Acronyms}

$\begin{array}{ll}\text { BISP } & \text { Benazir Income Support Programme } \\ \text { CBO } & \text { community-based organisation } \\ \text { CPEC } & \text { China-Pakistan Economic Corridor } \\ \text { DISCO } & \text { state-owned and operated distribution company } \\ \text { FGD } & \text { focus group discussion } \\ \text { GENCO } & \text { state-owned generation company } \\ \text { GWh } & \text { gigawatt hour } \\ \text { HSR } & \text { Huaneng Shandong Ruyi (Pak) Energy Ltd } \\ \text { IDC } & \text { Interest During Construction } \\ \text { IMF } & \text { International Monetary Fund } \\ \text { IPP } & \text { independent power producers } \\ \text { kWh } & \text { kilowatt hour } \\ \text { LNG } & \text { liquefied natural gas } \\ \text { MNA } & \text { Member of the National Assembly } \\ \text { MW } & \text { megawatt } \\ \text { NEPRA } & \text { National Electric Power Regulatory Authority } \\ \text { PMLN } & \text { Pakistan Muslim League Nawaz } \\ \text { PPP } & \text { Pakistan People's Party } \\ \text { PTI } & \text { Pakistan Tehreek-i-Insaf } \\ \text { PYF } & \text { Progressive Youth Front } \\ \text { TDS } & \text { tariff differential subsidy } \\ \text { URL } & \text { Uniform Resource Locator } \\ \text { WAPDA } & \text { Water and Power Development Authority } \\ & \end{array}$




\section{Introduction}

Between 2007 and 2015, Pakistan witnessed over 400 contentious incidents including but not limited to marches, rallies, sit-ins, protests, and riots - related to provision of and access to electricity. These incidents map on to a particularly troubling decade for energy provision and stability, during which the country experienced crippling electricity shortages that, at their peak in 2012-13, saw outages exceed 14 hours per day. This crisis of provision swiftly transformed into a prolonged public and political crisis, one driven by mass anger and resentment at not just the management of energy provision by the state, but broader facets of governance failure and corruption.

Public anger at electricity outages in Pakistan, which in many instances became extremely violent, provides us with a useful lens to study issues pertaining to popular mobilisation and public accountability in a setting historically characterised by authoritarian forms of government, weak political parties, lack of 'mobilising structures' within civil society, and various axes of violent conflict. This paper, then, draws on the case study of electricity-related contention between 2007 and 2015 in Pakistan, as part of a larger comparative study that aims to understand the conditions under which struggles over energy access empower people to hold public authorities to account.

While the crisis of electricity outages escalated after the global recession and resulting oil price shock from 2008 onwards, it took on immense political significance in Pakistan from 2011 onwards, dominating media and political conversations across the country. The 2013 General Election, Pakistan's second since its transition to procedural democracy in 2008, was labelled in its run-up as a referendum on the electricity crisis. The party that eventually won, the Pakistan Muslim League Nawaz (PMLN), was said to be successful because it, more than any other party, prioritised a resolution to the crisis in its campaign. ${ }^{1}$ And on some measures, it was able to deliver. Since 2015, outages (or 'load-shedding' in local parlance) declined from an average of 14 hours per day in 2012 to under 3 hours per day by 2018. Much of this is down to the China-Pakistan Economic Corridor (CPEC) collaboration, which is responsible for US $\$ 33 \mathrm{bn}$ of investment in the power sector through to 2022 by Chinese firms and associated joint ventures.

At the same time, however, problematic aspects pertaining to the financial and environmental health of the electricity sector continue to limit the actual extent to which the problem stands 'resolved', especially when it comes to key questions

All three main contending parties, the incumbent Pakistan People's Party (PPP), its main rival the PMLN, and the new challenger in 2013, the Pakistan Tehreek-i-Insaf (PTI) devoted considerable space in their manifestos to possible solutions to prolonged electricity outages. 
of energy affordability and sustainability for citizens. ${ }^{2}$ Given the chain of events during this period, this paper presents findings generated as part of research designed to help answer the following question:

\section{How and under which conditions do struggles over energy access in fragile and conflict-affected settings empower the powerless to hold public authorities to account over energy, or more broadly, over other issues?}

This paper draws together findings about these issues of contention over energy and its effects on accountability and empowerment in Pakistan. ${ }^{3}$ Briefly put, a range of factors contributed to the chronology and the selective, generationfocused nature of the response: (1) the cross-sectional socioeconomic and organisational nature of those impacted by the crisis; (2) the increasing cost imposed on public authorities by extensive protests; (3) the nature of the political opportunity structure available for opposition political parties to capitalise on the crisis; and (4) the pressures imposed from within key civil society actors, most dominantly, the private news media. These findings are elaborated upon in subsequent sections to build a causal narrative that can help us understand the way public authorities reacted to contention around electricity in Pakistan.

\subsection{Background and motivations}

Data on energy protests in Pakistan, collated for this project, showcase the pervasive nature of public mobilisation related to electricity. Between 2007 and 2015, there were 443 separate protest incidents, taking place in both urban and rural areas in all four provinces and what were at the time three federally administered territories of the country. ${ }^{4}$ Several of these incidents, particularly in the summers of 2011, 2012, and 2013, were part of elongated and multi-sited contentious episodes that lasted for several days on end, creating considerable unrest and posing law and order challenges for public authorities at the federal, provincial, and local level. Overall, 28 per cent of all protest incidents experienced some degree of violence on the part of either public authorities (police or paramilitary) or the protestors. ${ }^{5}$

2 As discussed ahead, the biggest challenge remains the cost of electricity, which results in 'circular debt' - the difference between a higher cost of generation (guaranteed by purchase contracts) and the lower cost at which it is sold to consumers, which is supposed to be met by the government. By February 2020 , the total stockpile of circular debt (outstanding differential arrears to be paid to various actors in the electricity supply chain) stood at just over US $\$ 11 \mathrm{bn}$.

3 While the overall project was motivated by a focus on energy protests in general, and fuel and fuel subsidy related protests more specifically, research in Pakistan was adapted to the issue of electricity access, subsidy, and pricing which, given the fuel mix for generation, is heavily linked to global oil pricing and related shocks.

4 On 31 May 2018, the Federally Administered Tribal Areas (FATA) were merged into the neighbouring province of Khyber-Pakhtunkhwa through the 25th constitutional amendment. The remaining two federally administered regions are Gilgit-Baltistan and the national capital territory of Islamabad.

5 Details on the collection and classification of protest data is provided in the methodology section. 
The scale of the protests due to the underlying crisis of electricity outages, when viewed in the light of Pakistan's significant history of authoritarian rule and the relative weakness of its civil society organisations, poses several interesting questions within the ambit of contentious politics: what factors made such mobilisation possible? To what extent can the protests be categorised as spontaneous 'eruptions'? What actors figured prominently in making these protests happen?

While these questions are important areas of enquiry, and are dealt with accordingly in this paper, what makes electricity protests from this period worth evaluating is the way the state ultimately responded to the crisis itself from 2013 onwards - in this case by prioritising massive investment in electricity generation, without adequate measures taken to improve affordability and sustainability.

The interaction between the outage crisis linked to global oil shocks from 2007 onwards, citizen struggles over access and the resulting scale of public contention, and the state's response from 2012-13 onwards stand to reveal interesting insights into the nature of accountability and empowerment around energy-related issues. Why did the state respond in the way that it did? What made a response that prioritised investment in generation possible during the 2013-18 period? What prevents other types of reform that prioritise sustainability and affordability of energy? These interactions, and the related questions they give rise to, serve as the primary source of motivation for both the Demanding Power project, and the Pakistan case study within it.

\subsection{The Demanding Power project}

People living with poverty and exclusion generally lack the power to hold public authorities to account. Their efforts to do so are likely to be tougher still if they live in fragile and conflict-affected settings, where the rule of law may be unevenly applied, civic space restricted, and rights violated with impunity. Yet, evidence also suggests that at key moments, and in defence of their basic needs, otherwise powerless people in such settings have occasionally mounted social and political action that has empowered them to demand a public response.

Centring on the increasingly important but under-researched issue of access to energy, this project comparatively explores how and when such social and political action emerges; how it manifests; its effects in terms of the services it secures and people's capacities to hold public authorities to account; and whether it feeds into longer-term dynamics of empowerment and accountability in fragile and conflict settings. The project involves in-depth work in Mozambique, Nigeria, and Pakistan. 
Within Pakistan, the project's focus is on electricity as the energy source of interest. As discussed at length in the subsequent section, this choice was motivated by the central role electricity plays in the lives and livelihoods of Pakistani citizens, and by the susceptibility of the country's electricity sector to global economic events, such as the 2008 recession and the resulting oil price shock. Vulnerabilities to adverse changes in the global economy puts Pakistan among a large number of countries where the state is expected to deal with the political and economic consequences of energy price volatility through subsidies and other interventions. At the same time, the fact that this relationship is particularly pronounced in the electricity sector also provides complementary insights on questions of how states manage developmental aspirations and citizen demands that are linked to the provision of large-scale infrastructure, such as power plants, dams, and grid sub-stations.

\subsection{Country context: the political economy of energy in everyday life in Pakistan}

\subsubsection{Electricity in everyday lives}

Pakistan's energy consumption is considerably diverse, with fuel, natural gas, and electricity playing an important role across rural and urban populations. The country is a net importer for its energy needs, with oil products and, more recently, liquefied natural gas (LNG), and coal constituting nearly 25 per cent of the entire import basket. A portion of total energy demand is met through domestic natural gas production of around 4 billion cubic feet per day (BCFD). Collectively, natural gas, oil, and coal account for almost 60 per cent of total energy consumption in the country. Across the country, and particularly intensively in rural areas, traditional fuels such as biomass, wood, and kerosene comprise around 40 per cent of energy requirements.

Natural gas, LNG, coal, and oil are also used as key inputs for the electricity sector. Pakistan's electricity consumption stands at around 600 kilowatt hour $(\mathrm{kWh})$ per capita. While this is still higher than the South Asian average, the electricity crisis since 2007 has led to extremely low annual growth in per capita electricity consumption, especially when compared to India and Bangladesh, both of which doubled their per capita consumption of electricity between 2007 and 2019.

Ninety per cent of Pakistan's urban population is connected to the electricity grid, while the estimate for the rural population is much lower at around 63 per cent. Overall, estimates using survey data place electricity access at 71 per cent of the total population, which means around 40 million citizens - overwhelmingly rural still lack access to grid electricity (IEA 2017). This gap is overcome through 
relying on indigenous energy sources as well as increasingly turning to standalone solar solutions, connected to battery arrays. While these have helped meet some household needs, such as lighting, fans, and small appliances, they fall some way short of producing energy for commercial and agricultural use.

\subsubsection{Electricity supply and system}

Pakistan has a semi-public/private electricity system. Transmission and distribution functions remain almost entirely in the hands of federal governmentowned and operated entities (except in the city of Karachi where a private entity runs a vertically integrated utility), while the private sector plays a significant role in electricity generation. The current system traces its origins back to the early 1990s that witnessed the 'unbundling' of the power sector under a large reform initiative led by the World Bank. The long-term objective of the reform was to create a competitive market in all three major arenas of the system (Burki 2007).

However, so far, the reform effort has only resulted in the introduction of private sector entities within electricity generation, labelled as independent power producers (IPPS). Various policy instruments, the first of which was issued in 1994, have determined the scope and terms of private sector activity in generation. Broadly speaking, the government acts as the sole buyer of electricity from producers, to whom it offers a set tariff as well as a guaranteed return on equity (Asif 2011). These terms were offered to encourage investment, which they were successful in doing but as discussed later in this paper, only at the cost of long-term affordability and financial viability of the sector. By 2020 , IPPs were responsible for 45 per cent of the total installed capacity of 36,010 megawatts (MW) in the country. Electricity purchased from IPPs is added to the public transmission system (along with electricity produced by state-owned generation companies - GENCOs) and then distributed to end consumers through the working of ten state-owned and operated distribution companies (DISCOs) (NEPRA 2020). ${ }^{6}$

Despite efforts to revise the fuel mix in recent years, the country remains heavily reliant on thermal sources for electricity generation. Coal, oil products, LNG, and domestic natural gas account for 58 per cent of electricity generated, while hydroelectric power (through the state-owned Water and Power Development Authority - WAPDA) accounts for a further 31 per cent. The remaining is divided between state-owned nuclear power and small-scale solar and wind-based generation. ${ }^{7}$ On the back of the supply/outage crisis between 2007 and 2015,

6 Pakistan's largest city, Karachi, has an integrated utility owned and operated by a private sector company called K-Electric (known as the Karachi Electric Supply Company prior to its privatisation).

7 The state's effort to shift away from oil as a source of electricity generation has been met with some success. The share of electricity produced using refined furnace oil has fallen from 30 per cent in 2013 to under 10 per cent in 2019 . However, the bulk of this shift has been towards coal and liquified natural 
total installed capacity has seen considerable gains in recent years, rising from $21,000 \mathrm{MW}$ in 2013 to $36,010 \mathrm{MW}$ in 2020. Total electricity generation has also risen from 98,213 gigawatt hours (GWh) to 133,615 GWh over the same period (NEPRA 2020).

\subsubsection{Electricity subsidies, financial viability, and the 2007-15 crisis}

Understanding the structure of energy (primarily electricity) subsidies in Pakistan requires an understanding of the system through which electricity is produced and distributed. Collectively the political economy of both factors - the subsidy and the supply and distribution system - are central in understanding the electricity supply crisis witnessed between 2007 and 2015, and the affordability and sustainability crisis that continues to date.

Electricity sector subsidies in Pakistan are primarily borne out of the difference between the cost of generating electricity and the price at which it is sold to consumers. Simply put, electricity generated has historically been more expensive due to a range of factors (fixed returns to generation companies, expensive input fuel, theft, and inability to recover electricity bills), while governments have largely been reluctant to charge the full cost to paying consumers. This difference between the determined tariff (actual cost) and notified tariff (rates actually paid by consumers depending on category and total consumption) is partially covered through a tariff differential subsidy (TDS) and is partially allowed to accumulate as a liability on the balance sheet of DISCOS (Lodhi 2017).

Subsidy outlays spiked after generation costs increased following the global oil price shock between 2008 and 2013. At their peak in 2011 - a period of considerable turmoil for the sector as a whole - the total subsidy reached 2.5 per cent of GDP (US\$4bn) (Kiani 2011). Since then, drops in the price of oil, gradual increases in tariffs, changes in the fuel mix, and some improvements in transmission and distribution governance have brought subsidy outlays to 0.4 per cent of GDP (US\$1.2bn) by 2018 (Zhang 2018).

Analysis of the incidence of the electricity subsidy shows that, while a larger share of households in the bottom deciles of per capita income lie in the bottom two or three consumption bands, a large share of those in all the remaining deciles also have consumption in those bands. Consequently, the subsidy which is nominally intended for the poor is, in fact, being consumed primarily by those of middle-income households. Furthermore, the poorest households are most likely to exist in remote rural locations and are thus unlikely to be connected to 
the grid itself, which means they do not benefit from the current structure of the subsidy (Bacon 2019).

Understanding the crisis of supply however also involves looking at the financial viability of the entire sector. In particular, the inability of the government to undertake large fiscal outlays (subsidies and payments) in order to keep the sector running has contributed to the crippling issue of circular debt, which in turn has contributed to outages. As explained in a recent diagnostic account by the Asian Development Bank:

'Circular debt' is the central problem of Pakistan's electricity sector. Circular debt arises because of non-payment of receivables all along the value chain. For example, theft or non-payment by certain customers, or tariffs which are below the cost of supply, mean that the revenues of the DISCOs are lower than their costs. As a result, they fail to fully remit their revenue to CPPA-G (the primary statecontrolled buyer for grid electricity in the country). Consequently, CPPA-G is not in a position to pay power suppliers in full, including both the GENCOs and IPPs. The power suppliers, in turn, delay payment to their fuel suppliers. When circular debt becomes too high, fuel suppliers may stop delivery of fuel, which then limits the amount of power which can be generated and supplied to households.

(ADB 2020: 175)

In other terms, the government is unable to pay different actors in the electricity supply chain, which results in generation going offline, even if installed capacity exceeds total demand. ${ }^{8}$ This is largely the story of the $2007-15$ crisis. As oil prices increased, ${ }^{9}$ generation became more expensive. Two successive governments (Musharraf's military regime, 2006-08, and the PPP government, 2008-13) remained reluctant to pass on the additional cost to consumers, or to raise more revenue by cutting down on transmission and distribution losses. Resultantly, as the financial burden of the sector grew in tandem with a stagnating economy, the government found itself without adequate resources to sustain generation, leading to prolonged outages.

Despite increases in generation capacity and a marginal reduction in overall cost of generation due to changes in the fuel mix and reduction in global oil prices, the spectre of circular debt continues to plague sustainability and affordability of the electricity sector. By the end of 2019, the government in its role as the sole buyer of electricity owed US\$7bn to electricity producers, alongside an additional

8 Transmission and distribution losses, delays in price determination and notification, delays in pass through of fuel price increases, poor revenue collections, delays in subsidy payments by the government to distribution companies all contributed to the growing circular debt.

$9 \quad$ Oil prices increased from US\$66 per barrel in 2006 to US\$145 in 2008. 
US $\$ 4$ billion owed prior to 2014 that was parked in a government holding company.

\subsubsection{Actors and interests in the electricity sector}

No baseline understanding of the complex nature of the electricity supply chain in Pakistan is complete without enumerating the large number of actors operating within it, and their various interests, incentives, and institutional configurations. This section provides a snapshot of the primary stakeholders and their relationship within Pakistan's power sector.

Electricity sector bureaucracy: Given the degree of government control in both the service-provision and regulation of electricity, the sector is largely managed and administered by career civil servants (generalists and technical specialists). These officials devise and implement important policy decisions, which shape the performance and effectiveness of the sector. Officials are motivated by both career incentives (lucrative postings and promotions) as well as rent-seeking and pecuniary incentives, through close ties with private-sector actors involved in generation, construction of electricity infrastructure, and procurement.

IPPs: Private investment in the power generation sector began in the late 1980s with the establishment of Hub Power (to date, Pakistan's biggest IPP) and was formalised under the 1994 Power Policy. Subsequent years have seen later iterations of the policy framework regulating private investment in the generation sector. As a result, several international firms and major industrial conglomerates controlled by powerful businessmen have set up mostly thermal energy-based power plants, thus increasing total installed capacity in the country. In 2020, a major government report on IPP performance highlighted policy and regulatory capture, which has allowed IPPs to accumulate considerable profit through government guaranteed capacity payments and returns on equity while flouting regulations related to efficiency and sustainability.

Electricity sector labour unions: As majority government-owned entities, all service delivery organisations provide the right of unionisation to their employees. Over time, this has resulted in the development of powerful and thoroughly entrenched worker unions, especially in WAPDA/DISCOs. The biggest and most active amongst these unions is the WAPDA Hydroelectric Union representing DISCO employees across the country. The WAPDA Hydroelectric Union remains committed to an anti-privatisation agenda, in a bid to protect benefits and perquisites as public sector employees. It has, in the past, successfully blocked the privatisation of the more efficient DISCOs as well as of various parts of the transmission and distribution set-up.

Industrial and commercial consumers: Organised along the lines of various business and trade associations and chambers of commerce, industrial and 
commercial consumers constitute an important voice in the policy-making domain of the energy sector. Industrial consumers, for example from the textile sector which utilise gas-captive power plants, lobby the government on energy pricing; the duration of power outages; and the supply of electricity during the winter months. Industrial and commercial users often resort to closure strikes and protests to pressurise the government on access and pricing related issues.

Domestic consumers: Government policymaking in the sector is often undertaken with the impact on the end-consumer in mind, especially in the aftermath of the power supply crisis 2013. Rising costs of electricity along with prolonged outages have resulted in spontaneous protests and mass unrest in major urban centres, especially in Punjab. Given the high importance domestic consumers place on energy availability, the government has been reluctant to remove the existing untargeted subsidy and to rationalise overall tariffs.

Politicians: The provision of electricity connections has been used as a political public good for the majority of the last three decades. Politicians, thus, have become important stakeholders in determining which areas gain access to energy supplies, for which in return they are able to garner votes during election time. Their political success is also tied to the availability of electricity hence they have an active stake in the way DISCOs manage electricity load shedding and how the federal government determines its subsidy structure. This has strong implications for any holistic energy sector reform proposed by higher levels of government. Sections of the political elite also exercise an active interest in the rents accrued from electricity sector contracts with IPPS. This inevitably deincentivises them to push down too much on the supply-side cost of generation, while voter pressure forces them to keep consumer tariffs low as well.

Judiciary: Over the past seven years, the High Court and the Supreme Court have been involved in several high-profile cases involving the energy sector, especially in relation to rule violations in procurement; charges of corruption; and non-compliant appointments. Such public interest litigation, often initiated by the judges themselves, has elevated the higher judiciary to the position of an important stakeholder in the energy sector.

Media and civil society: The recent proliferation of electronic media outlets and the parallel rise of civil society organisations working in the realm of consumer rights and government transparency, has increased general awareness about government administration and policymaking. Various news channels have devoted lengthy segments to airing public opinions on the energy crisis (usually giving space to outrage over shortages), and some have even conducted responsible, informative shows on tariff rationalisation and electricity theft.

Donors: Pakistan's electricity sector's governance and evolution has long been impacted by the presence of international donors, most notably the World Bank 
and the International Monetary Fund (IMF). The World Bank was a key player in the sector reform process that led to the unbundling of generation and regulatory functions, as well as the separation of the hydroelectric development arm from thermal generation within the state utility. The IMF has played a key role in shaping fiscal outlays on the electricity sector, advocating for subsidy reform and improving targeting of the subsidy itself, often as part of stabilisation agreements with the government. In recent years, the ADB and the United States Agency for International Development (USAID) have also stepped up their support to the power sector, mostly in the shape of driving technical assistance in the transmission and distribution domain.

The Chinese state: China's footprint on Pakistan's economy and politics has grown over the past decade. The main vehicle for this has been the CPEC, a series of Chinese state debt-funded ventures implemented by Chinese companies primarily in road and coal, hydroelectric, and natural gas electricity infrastructure across Pakistan. As a result, Chinese government-owned companies now have a considerable stake in the electricity sector as a whole and are in a position to influence policies related to electricity sector regulation, returns on investment, tariff determination, and environmental sustainability. 


\section{Approach and methodology}

The Demanding Power project, of which this research is a part of, set out a three-part approach for the analysis of contentious struggles around energy in fragile contexts:

- Comparative analysis across different types of political system and energy regime, to enable the testing of propositions and mid-range theories.

- Analysis at multiple levels of the system, to capture differential experiences and levels and forms of power among the different actors.

- In-depth analysis and process tracing to document empirically and enable identification of the mechanisms of impact.

These requirements indicate the need for a mixture of qualitative and quantitative data collection and analysis, to generate evidence that is grounded in the specifics of each context, but which also generates generalisable lessons about whether contention over energy empowers the powerless to hold the powerful to account and, if so, how.

Primary fieldwork for the overall project, focused on three countries, Mozambique, Nigeria, and Pakistan, with some additional comparative analysis of data for a set of other countries, selected to test specific propositions about the relationship between social and political action around energy and fragile and conflict- or violence-affected settings. The research itself has been organised into three components:

Component 1. Energy demands in everyday life: Working in selected rural and urban sites in each of the three countries, this component of the project focuses on understanding what people's energy demands are in everyday life, and how they go about securing their needs, including their individual and group negotiations and strategies with local public authorities and others responsible for energy supply.

Component 2. The political economy of energy policies and protests: This component involves a full and detailed analysis of the political economy of energy policies and protests in each country. This is based on a literature review of the political economy of energy consumption and energy policies for each country, a review of data sources, media content analysis of episodes of contention according to agreed methodology, key informant interviews and focus group discussions (FGDs) with activists involved in particular episodes or ongoing contention emerging out of energy struggles.

Component 3. Energy struggles, empowerment and accountability in fragile and other settings: This component is designed in part based on the 
results of the literature and data review in Component 2. This component helps test hypotheses about whether/the extent to which, (a) fragile and conflict affected settings may be more prone to energy protests; (b) energy protests empower people to hold public authorities to account more broadly; and (c) the role and influence of external actors on such events.

The methodology overall is an innovative mixture of approaches designed to uncover and combine a range of explanations for whether and how energy protests lead to empowerment and accountability in fragile and conflict-affected settings. The chief methodological innovation is its combination of multiple perspectives that cut across levels of social and political action, so that the project seeks to bring together understanding of the energy demands of individuals, the sources of collective grievances and collective action around energy, and the transnational influences on such action. It also collects evidence on the material dimensions of struggles (prices, points of access, transport and electricity needs; levels of corruption); on their subjective, experiential, ideational (moral economy ideas, human dignity and natural rights, experiences of state repression) aspects; and on the mechanisms through which they are communicated (the news media, popular music, demonstrations and slogans).

\subsection{Pakistan case study methodology}

Research for the Pakistan case study involved several sources of mixed-method data collection. Primary research for the first component of the study was carried out through five FGDs (with 42 participants in total) and eight in-depth interviews with protest organisers, participants, and observers in two select localities (Kot Lakhpat/Chungi Amer Sidhu, Lahore; and Kamalia town, Toba Tek Singh) that had been the sites of prolonged public mobilisation and 'unruly' contention over electricity shortages. In Chungi, a working-class neighbourhood in the city of Lahore, separate FGDs were carried out with protest organisers and participants, both men and women. In Kamalia, discussions were carried out with members of the Kamalia market traders' association (Anjuman-e-Tajran) who played a central role in organising and financing electricity related protests between 2007 and 2015.

These FGDs helped secure valuable information on the dynamics of protest, who the protesting publics were, the organisational basis on which demands were made to public authorities, and the role played by political actors (politicians, party activists, and government officials) in electricity-related contention. They also illuminated the centrality of electricity to the lives and livelihoods of citizens and shed light on the textures and modalities of statecitizen interaction over electricity access.

The information gathered through FGDs was selectively supplemented with community key informant interviews in order to obtain more information on 
mobilisation, contention, and everyday struggles over energy from particular members of the community (activists, local organisers, local notables).

Research for Component 2 of the study was carried out in four stages. The first was the development of the events catalogue of electricity related contention. The second was process tracing, using secondary sources, the history of electricity reform, the genesis and layout of the crisis along with the political economy context of contention, and finally mapping out the response of public authorities. The third was plugging gaps in the process tracing by conducting 18 key informant interviews with politicians, electricity sector officials, donors, academics, and policy advisors who were involved with the electricity sector between 2007 and 2015 . The fourth and final stage was collating representations of the crisis in popular culture by looking at internet discourse, media representations, YouTube videos, satire, and references in music, television, cinema, and other cultural output during this period.

\subsection{The Demanding Power Pakistan events catalogue}

The Pakistan Demanding Power data set substantively builds on existing protest data to compile a comprehensive catalogue of 456 incidents of contentious politics around electricity access, availability, and pricing from 2007 to 2015.

There were two primary data sets that were used to mine the initial data:

- The BFRS political violence data set, which covers all violent incidents in Pakistan reported in the daily Dawn (Lahore edition) between 1988 and 2011. The BFRS data set has a sub-category of service delivery protests around energy (fuel and electricity). It also has sampled verification of its incident universe using an alternative media source. However, its utility was limited by its definitional use, which covered protests that involved some element of violent contention (arson, rioting, casualties).

- The Ahsan Butt-GMU protest data set, which covers 4,123 protest incidents in Pakistan, reported in the daily Dawn (online edition) between 2005 and 2009. The ABGMU records protests by type of actors involved but does not provide cause of protest.

Fourteen energy incidents from the BFRS data set were identified using the existing categorisation. For the ABGMU data set, a careful string search of all 4,123 protest incidents was carried out using the terms 'electricity', 'energy', 'protest', 'riot', 'load-shedding', 'outages', 'power', 'tariffs', and combinations of these terms, to identify 261 incidents. These were then cross-checked to ensure there was no overlap with the 14 incidents identified from the other data set, and 
duplicates were deleted. Web addresses (URLs) linking to the news report of each incident were recorded in a separate column.

For 2010-15, the online edition of Dawn newspaper was used with the search terms mentioned above. The benefits of the online edition are that it captures news stories from all regional bureaus of the newspaper, thus providing a more comprehensive overview. In this phase, a further 442 incidents were recorded by date of publication, location (district level), headline, and reported incident URL. In the second phase, each news report was manually assessed to extract key pieces of information including more granular location data, identity of protestors, and other variables developed for the events catalogue template.

The use of Dawn to identify events is standard practice in academic research on Pakistan. It is regarded as Pakistan's only English-language newspaper of record inside and outside the country, possesses an extensive reporting network, and generally has a non-partisan reputation. However, the following issues are worth flagging:

- Dawn's main bureaus are located in five cities (Islamabad, Lahore, Karachi, Peshawar, and Quetta). While these provide good coverage across each region, the reporting network in peripheral areas is unlikely to be as effective. News stories from those regions compete with stories from other locations at the bureau level for relatively small amounts of reporting space. Thus, the events catalogue cannot be taken as comprehensive of all power-related contentious action during this period, but it covers all significant episodes that took place during this period.

- Vernacular papers (Urdu-language) have more regional editions, which means there is less competition for publication space. They are likely to both cover a greater number of protests and provide more granular details of each protest. Given their reach, we relied on Urdu-language newspapers to accumulate details about particular protest events that had taken place in the two primary field sites of Chungi Amer Sidhu and Kamalia town. 


\section{Political fragility and the escalation of energy struggles}

Why do struggles around energy specifically appear to have the potential to grow into significant episodes of contention within settings where political authority is fragmented or fragile, and conflict and violence common? Do such features help to explain major movements or struggles around energy? This study explored the relationship between fragility and energy protests, developed on the basis of a review of the literature on the political economy of fossil fuel subsidy reform and the contentious politics of food and fuel (Hossain et al. 2018).

One mechanism proposed to connect fragility to the escalation of energy struggles was that fuel subsidies are a more important part of the social contract and of social protection in less stable and weakly governed states, and in resource-rich/energy exporting countries (which overlap to a considerable extent because of the 'natural resource curse').

Pakistan's case study provides interesting reflections on this by both affirming and departing from the suggested mechanism. Electricity access and subsidies are certainly an important part of the social contract between the state and sections of society, even though Pakistan is not an energy exporting country. However, there are two particular aspects to this relationship which link it back to the development of contentious politics. The first of these is the historical role of electricity grid access and expansion as a signifier of developmental progress, especially for urban consumers. As Naqvi $(2016,2017)$ highlights, since at least the 1980s, electricity access has been utilised by successive democratic and authoritarian regimes in showcasing their developmental commitment and credentials. One outcome of the rapid expansion of the grid is that urban consumers, in particular, have become accustomed to seeing access to electricity as a state-granted prerogative, one which is defined as an intrinsic part of the social contract with the state. ${ }^{10}$

FGDs in the working-class locality of Chungi Amer Sidhu in Lahore affirmed this widespread expectation from the state. Most respondents believe that the state is ultimately responsible for providing electricity at a 'fair price' and that a failure to do so amounts to a failure in governance. One respondent vocalised her expectation by pointing out that 'if the hakoomat [government] is not ensuring that our fans stay on during the summer months, what good is it there for?'

10 The literature on politics around the electricity sector in Pakistan is extremely sparse. Most written work approaches the issue from a technocratic/policy perspective, with diagnosis of long-standing ills and suggested recommendations. Apart from ljlal Naqvi's excellent work, citizen engagement with the sector and how this feeds into politics is sorely lacking. 
This expectation of access/supply and affordability thus plays an important role in how citizens react to perceived disruptions in the contract, or, in other words, to the obligation of the state towards them.

The second aspect is the role of the subsidies and their actual outlay, over and above annually budgeted amounts, that attempt to ensure that electricity supply is guaranteed. Subsidies are given as the cost of electricity generation exceeds the cost at which it is sold to consumers. In other terms, Pakistan's case reveals that taking away TDSs would lead to electricity becoming much more expensive for large sections of the consumer base.

Interviews with politicians and DISCO officials illuminate this dynamic. Several categories of urban groups (shopkeepers, small business owners, middleincome locality residents) are found to be more vocal and better connected to decision makers, and thus able to engage in lobbying and protesting for continued electricity access, preferably at suppressed rates (Walker et al. 2016). Therefore, the government's failure to continuously provide an escalating TDS to IPPs becomes a central reason for generation shortcomings and thus outages, which has led to extensive political escalation in electricity related contention.

As a former Federal Minister for Water and Power put it succinctly:

No government has ever come in explicitly saying it will give people more subsidies. It always comes in saying we will give you uninterrupted electricity. But the two are linked because the government can't change the cost of generation, it can only pump in more and more money from its own pocket to buy that expensive electricity and sell it to consumers for a cheaper price. When the money runs out, the electricity runs out and then people come out on the streets.

The twin dynamic of consumer expectations of state obligation towards access/supply, and the role of subsidies in ensuring that obligation underlies the mechanisms through which subsidies are connected to escalations of energyrelated struggles in Pakistan.

The literature also proposes that in fragile settings where energy subsidies are an important part of the social contract and/or social protection, subsidy regimes are likely to come under fiscal pressure, whether from domestic or external sources.

The Pakistan case affirms this tendency in fragile contexts, given the way that the electricity crisis starting in 2007 was connected to both exogenous changes in the cost of generation (due to the oil price shock) as well as the stagnation of economic growth, which drastically reduced the fiscal space available to the government to bear the TDS. Over the last three decades, Pakistan's economic 
conditions have fluctuated between periodic boom and bust cycles, with periods of low/stagnant growth becoming increasingly frequent. Successive governments have also struggled to increase exports to pay for energy-related imports, and to expand the state revenue base by raising the tax to GDP ratio from a multidecade average of 12 per cent (Javed and Nabi 2017).

These two trends have culminated in spiralling fiscal and current account deficits resulting in repeated bailouts by the IMF. In 2019, the country entered its 11th IMF programme in 30 years on the back of yet another balance of payments crisis. Successive IMF programmes have advocated for a rationalisation of electricity-related subsidies (both tariff differential and consumer) to bring down fiscal deficits and create alternative mechanisms of social protection in energy markets. IMF and other donors continue to argue for improved transmission and distribution governance as the primary reform thrust, so that losses can be reduced, recovery rates improved, and overall cost of electricity goes down. They have also advocated for the privatisation of DISCOs, which continues to be opposed by the electricity sector labour unions (Naqvi 2017).

Empirically, the headline features of Pakistan's economic fragility - anaemic growth and capacity failures to broaden the tax base - produced particularly stark consequences in the 2007-15 period, which coincided with the global recession and oil price shock. With little fiscal space to begin with, the crises severely hampered the state's ability to undertake further outlays on electricity subsidies to ensure supply. The resulting outages also contributed to the preexisting fragility in two ways; first by causing a loss of upwards of 4 per cent to GDP growth by hampering economic activity, undermining the economy even further; and second, by the escalation of public anger that led to widespread mobilisation and periodic outbreaks of violence.

The presence of economic fragility and vulnerability to external shocks provides the context in which energy struggles germinate and escalate. A central part of the mechanism chain that links these contextual factors with rampant escalation of struggles is the way that energy sectors are usually managed in fragile contexts. In Pakistan, governance of the electricity sector remains firmly in the hands of the federal government bureaucracy, international donors, and a small section of top political officials. There is little to no parliamentary or citizen oversight of decision-making on key issues, such as the guaranteed returns offered to private electricity producers, tariff setting, subsidy outlay, and other aspects of sector reform.

Interviews with elected representatives from government and opposition parties, who should theoretically have greater oversight of and input into policy processes, confirm the non-participatory and unaccountable nature of decisionmaking in the sector. One treasury bench Member of the National Assembly (MNA) said that he has to rely on personal goodwill and 'informal ties' with 
DISCO officials in order to get electricity infrastructure (like transformers, wires, and poles) upgraded. Another politician, an MPA in a dense urban locality, said that on several occasions he has had to pay for basic repairs for a transformer in his constituency out of his own pocket, given the cumbersome procedures put in place by the electricity sector bureaucracy.

FGD feedback highlights citizen frustration at the way the sector is managed as a whole. Local community elites report the frequently frustrating yet necessary nature of cultivated ties with street-level bureaucrats from DISCOs in order to resolve issues of access and supply. Many of these relationships involve some form of quid pro quo, either in the shape of bribes or favours, and operate as the most stable arrangement for citizen grievance redressal. However, when these relationships fail to deliver, especially when the sector is under stress and fieldlevel staff operate with reduced autonomy, communities tend to leverage elected representatives to bargain on their behalf. The success of such efforts is by no means guaranteed, and interviewees assert that it is contingent on personal resources, and the elected representative's ties to the bureaucracy and his or her position of influence within the party, suggesting the insulated nature of the power sector.

The unaccountable nature of the sector was highlighted sharply through the findings of a recent report on financial practices within electricity sector governance, released in April 2020. Among many aspects, coverage of the highly lucrative terms of contracts between IPPs and the government, and the failure of regulatory oversight to ensure efficiency, strongly suggest the presence of rent-seeking relationships between different national-level business, bureaucratic, and political elites linked to the sector (Government of Pakistan 2020). ${ }^{11}$

Media reporting of such revelations tends to reflect underlying sentiments of anger and disillusionment among the citizenry. The notion of the electricity sector being rife with muk muka (reciprocal corruption) is widespread, and as FGDs reveal, citizens perceive themselves to be disempowered as far as most decision-making matters within the sector are concerned.

11 A report on suspected contract violations by IPPs which have cost the Pakistani exchequer billions of dollars, reveals that IPPs have been generating profits of up to 70 per cent, as against the 15 per cent limit set by the NEPRA. Most IPPs had an investment payback period of 2-4 years, profits generated were as high as 18.26 times the investment, and dividends 22 times the investment. Under the 1994 Power Policy, 16 out of 17 IPPs invested a combined capital of PRs $51.8 \mathrm{bn}$ and earned profits in excess of PRs 415bn. The government's failure to contain the circular debt has cost the country over PRs 4,082bn (approximately US\$30bn in 2020) in the past 13 years, with an annual loss of PRs 370bn. 


\section{Energy protests and accountability for energy provisioning}

A second set of research propositions addressed the possibility that protests about energy enabled citizens to hold governments to account for energy provisioning, or indeed other issues. A review of the literature suggests that protest episodes that persisted, diffused beyond an urban centre, and gained national and international attention had achieved 'voice', an important element of accountability. This particular proposition was explored through analysis of a catalogue of energy protest events. Data collected for the events catalogue shows that between 2007 and 2015, Pakistan witnessed 456 contentious incidents related to electricity supply, access, and pricing. ${ }^{12}$ Of these, roughly 10 per cent (42) could be counted as incidents that formed part of a protest episode - a collection of contentious acts that lasted for more than a day and took place in several different localities at the same time. Of these, four such protest episodes stand out due to their spatial diffusion, scale of escalation, and prominent use of violence as a tactic:

- 31 December 2008 - 3 January 2009 (national)

- 1-3 October 2011 (Punjab)

- 19-25 March 2012 (national)

- 12-19 June 2012 (Punjab)

Among these four, the October and June protests started from one particular locality (Lahore and Kamalia respectively) but quickly spread to a number of big and small urban localities. ${ }^{13}$ Both episodes received considerable attention, including in international press outlets.

Key informant interviews confirm that these protest episodes played a prominent part in how the electricity crisis was being understood and was ultimately responded to by decision makers in the country. The June 2012 episode, which was documented in detail for this case study, stands out in particular during the interviews because of the scale of violence and rioting that accompanied the

12 Descriptive statistics from the events catalogue are provided in Annexe 1.

13 Another reason for the expansive coverage given to the October 2011 and June 2012 protests is due to their escalation in the province of Punjab, Pakistan's wealthiest and politically most salient region.

Punjab is home to 54 per cent of the country's population, sends the highest number of legislators to the federal parliament, and was perceived to be worse hit than other provinces as far as electricity outages were concerned due to its lack of indigenous fuel/energy resources. The provinces of Sindh and KhyberPakhtunkhwa both had fewer outages than Punjab, on account of their production of natural gas and hydropower resources. FGD responses show that there was also a widely believed story of 'victimisation' on the part of the federal government, which was, until 2013, in control of the largely Sindh based PPP, while Punjab was governed by the PMLN. 
protests which led to the death of ten people. These episodes played an important part in elevating the electricity crisis to a position of political primacy for both citizens and public authorities. By 2013, survey data shows that citizens reported electricity outages as their number one concern, even more so than the concurrent wave of Islamist militancy and terrorism that began in 2005. ${ }^{14}$

The research also explored whether or not such struggles went from enabling or amplifying voice to giving it 'teeth' or 'holding power' of sufficient magnitude to compete for governmental action with more conventionally powerful pressures. The framework proposed that the protests needed to demonstrate the capacity to incur significant economic or social costs or disruption to major centres, and to attract widespread public support or important political champions to qualify as having 'teeth' as well as 'voice'.

The impact of electricity-related contention on public authorities, visible in the nature of political discourse during this period and the urgency of the response showed after the 2013 General Election, was made possible not just because of the number of incidents that had taken place, but also because of their location and intensity as well. In this regard, the fact that some of the most violent protests (between 2010 and 2013) took place in the wealthiest and politically most salient region of North and Central Punjab played an important role in shaping political perception and eventually, governmental action. The fact that from 2008 to 2013, different political parties governed the federal and Punjab governments (with the former being responsible for the management of the electricity sector) also added an additional salience to the way the protests were perceived.

Within the cases identified above, the June 2012 protest episode was characterised by extensive economic and social disruption in different parts of the country. Data collected from newspaper accounts suggest that at least seven properties belonging to electricity sector companies (primarily government-run DISCOs) were ransacked in different cities. A number of police vehicles were torched, especially in the city of Kamalia and Rawalpindi, where the protests became the most violent.

Primary aspects of economic disruption included a three-day blockage of the main North-to-South national highway near the district of Toba Tek Singh, Punjab, in June, where police and security guard action against rioters led to the death of two individuals. Major market associations as well as industrial bodies

14 Between 2005 and 2015, Pakistan experienced significant violence in terms of frequency, scope, and magnitude. An examination of the incidence of violence during this period reveals a variety of conflict actors, new and old (including armed domestic and transnational non-state groups); varying patterns of violence in different regions, both high and low intensity in nature; and an unprecedented number of civilian and law-enforcement casualties, estimated to be upwards of 50,000. 
across the country carried out 'shutter-down' strikes, ending all economic activity during this time period (Boone 2012).

An important point to note here is the cross-sectional nature of the 'protesting public', which greatly enhanced its salience in shaping government action. The protests were not just populated by political activists and workers but were planned and coordinated by sections of the urban business classes, in particular traders, merchants, shopkeepers, and other bazaar-based actors. Data from the events catalogue highlights that traders and associated businesses were the second most frequent segment involved in electricity related contention. ${ }^{15}$ Urban political economy accounts of contemporary Pakistan, such as those by Akhtar (2018) and Javed (2017), identify traders and associated businesses as a politically salient demographic, given their role in financing political activity at the constituency level and their status as local community leaders. Furthermore, opposition parties were quick to capitalise on public anger as it gave them a chance to demonstrate their representative credentials with key urban demographics.

Analysis of existing work on contentious politics around energy suggests that governments would be likely to combine temporary concessions with active repression of energy protests, and efforts to prevent or pre-empt such protests to facilitate future rounds of subsidy reforms.

However, research on similar dynamics in Pakistan between 2007 and 2015 reveals that the reaction of public authorities to electricity protests was infrequently repressive. Using the events catalogue, out of the 242 incidents of contention where definitive public authority response was recorded, only 8 per cent saw police using force to disperse protestors. ${ }^{16}$ These incidents were the most violent electricity riots (such as those in October 2011 and June 2012), where government infrastructure and private property of politicians associated with the ruling party was directly damaged. ${ }^{17}$ On the other hand, the most common outcome ( 42 per cent) was protracted negotiations between protestors and local DISCO officials, mediated by the police and district administration, to limit unscheduled outages. These were also most likely to be the cases where outage problems were restricted and thus protests had not spread to other localities.

An important reason for the generally low levels of police action is the political dynamic that governed different tiers of decision-making between 2008 and 2013.

15 Occupational details of protestors, where available, are given in the Annexe.

16 An even smaller number of incidents $(n=3)$ involved paramilitary authorities, such as the Punjab Rangers, being called in to quell the protests.

17 The June 2012 riots originated from a protest against outages directed against a Federal Government Minister, Riaz Fatyana, in his hometown of Kamalia. Fatyana accused the police of inaction during the initial protest, compelling his personal guards to open fire in order to control the situation; this in turn set off an escalatory spiral that culminated in extensive rioting. 
The PPP-controlled federal government from 2008 to 2013 frequently accused the PMLN-led Punjab government of not clamping down on protests as law and order was a provincial subject, and it allowed the PMLN to stoke sentiment against the federal government for political gain. Interviews with PMLN representatives and members of the local district administration in the cities of Lahore and Kamalia/Toba Tek Singh hinted that urgency for police action only kicked in once damage to private property became a real possibility, while road blockages were tacitly permitted to allow protestors to 'vent'.

In one interview, an important member of the municipal administration (an Assistant Commissioner) in the city of Bahawalpur, who was posted there during 2012, mentioned that police themselves were reluctant to take action against protestors due to shared circumstances. As the electricity crisis impacted every citizen, working and middle-class policemen would often face the same shortages in their workplaces and residences, and thus empathised with citizen anger. In order to curtail damage, the local administration would often use informal ties between businessmen and political leaders as leverage in the community to request protestors to dissipate. Formal action was normally used in the last resort, and only after explicit political approval had been granted by the provincial government.

Beyond calling for police action, the federal government's immediate response to escalating protests during the 2008-13 phase was to make temporary measures to restore electricity supply. This involved period release of non-budgeted amounts of subsidies in order to pay for natural gas and oil that could enable electricity generation to take place. In October 2011, for example, after protests entered into their third day and with outages approaching 12 hours per day in urban centres, the government mandated the emergency release of US $\$ 120 \mathrm{~m}$ for the purchase and supply of refined furnace oil to two major IPPs.

Another response seen during this time period was to provide temporary relief from outages in areas witnessing electricity-related protests by diverting from other zones within the grid. The data required to establish this strategy systematically is hard to come by; however, interviews with DISCO officials who served in sub-divisional jurisdictions where protests were prominent mentioned that they would receive calls from higher officials to revise outage schedules based on law-and-order concerns. ${ }^{18}$

A further proposition regarding accountability following energy protests is that policy reform proposals would be likely to include significant efforts for inclusive

18 It is not easy to establish just how frequent such decisions were made and more information is needed through interviews and transmission dispatch data. Scheduled outages of 4-6 hours per day were already built into the system and communicated to consumers on a regular basis. Most of the public anger would be about unscheduled outages, especially those that exceeded 8-10 hours. Diversions of electricity from one neighbourhood to another can only take place at the sub-divisional level. 
and participatory policy spaces, consultation with affected groups, attention to the impacts of subsidy reforms on poverty and inequality, etc., and policies for addressing those adverse effects.

Pakistan's experience with electricity sector reform from 2013 onwards highlights the entrenched persistence of insular and highly centralised governance practices in key areas of governmental decision-making. However, the response to escalating struggles over electricity access did not transform the institutional architecture of policy formulation and implementation in any meaningful way.

The 2013 General Election was contested as a referendum on the electricity crisis. Its results showed voters penalising the previous incumbent, the PPP, for its management of the crisis, especially in the worst-impacted part of the country, Punjab. Its successor, the PMLN, had campaigned on a platform slogan of Roshan Pakistan (Bright Pakistan), a nod to its intent to end prolonged outages and kickstart the economy. The messaging clearly resonated with the public, as it swept two-thirds of the seats available in the province of Punjab, and ended with a clear majority in the federal legislature.

The reform strategy adopted, however, was highly centralised and technocratic in nature. The then prime minister, Mian Nawaz Sharif, put together a small team of handpicked bureaucrats, political confidantes, policy advisors, and sanctioned the hiring of an international management consulting firm, to prepare a roadmap to end outages. ${ }^{19}$ External support was drawn in from the World Bank as well as the Chinese government which fronted approximately US\$33bn in concessional loans under CPEC to improve generation and transmission capacity.

Interviews with elected representatives from the PMLN highlight that the government was mindful of public sentiment on the electricity crisis and understood that its electoral future rested on a quick redressal of the problem. However, the highly centralised ethos of the party and its preferred strategy of governing through bureaucrats and technocratic appointees dictated the modalities of its reform agenda. Parliamentary oversight, for example, which might have institutionalised some form of participation and inclusion of citizen voice was ignored throughout this time period.

This became particularly apparent as the government entered into a number of agreements with the Chinese on enhancing generation capacity. As with previous rounds of foreign and local private investment in the generation sector, this time, too, the terms offered to Chinese contractors and investors between 2013 and 2018 were neither publicly debated nor submitted to parliamentary scrutiny. Resultantly, by 2020 , the next government's investigation into the fiscal failings of the electricity sector revealed that the new generation capacity

19 Information on who was leading the electricity reform process was never made explicitly public by the government; this information was gathered through key informant interviews. 
inducted within this decade had helped change the fuel mix and reduced dependency on imported oil, but had not reduced the overall fiscal burden of generation (through fixed purchase tariffs and capacity payments) by much (Government of Pakistan 2020).20 This view is echoed by the power sector regulator NEPRA in its State of Industry Report 2020, which once again raised the issue of validity of power purchase agreements executed by the federal government with private producers, as well as 'excess' payments made to them and the accumulation of massive circular debt due to the costly nature of generation (NEPRA 2020).

Finally, the continued insularity of the reform process is also demonstrated by the fact that while the PMLN government was successful in ensuring adequate electricity supply - partly because of reduced generation costs due to a fortunate decline in oil prices from 2014 onwards and partly because of the influx of new generation capacity that changed the fuel mix - it did not pay adequate attention to the complementary issue of electricity affordability, which afflicts the poorest consumers. Successive increases in consumer electricity tariffs to bring them closer to the cost of generation (as recommended by the previous two IMF programmes), and a failure to meaningfully improve DISCO governance that would reduce distribution losses/thefts/non-payments and decrease pressures on the determined tariff, showcase that even after the crisis public authorities do not prioritise affordability and financial viability of the sector as an important pillar of the reform process. ${ }^{21}$

20 The inquiry report revealed that in March 2015, the Huaneng Shandong Ruyi (Pak) Energy Ltd (HSR) for 2x660 MW coal-based thermal plants submitted a cost assumption of US $\$ 145.59 \mathrm{~m}$ against Interest During Construction (IDC). After the 'commercial operation date', HSR submitted revised tariff rates of IDC in January 2019 amounting to US $\$ 197.33 \mathrm{~m}$. HSR had claimed IDC based on mark-up or long-term London Interbank Offer Rate (LIBOR) plus 4.5 per cent during the entire construction period, whereas the financial statements of the company revealed that it did not borrow any funds in the first year of construction and obtained short-term loans at subsequently lower interest rates during the second year of construction.

21 The determined tariff remains high because it includes allowances for theft and non-payments as well as technical losses due to the transmission infrastructure. Improvements on these fronts would reduce the cost of electricity as it would reduce the gap between the determined tariff and the notified tariff at a lower overall level, and reduce the fiscal outlay the government has to make to ensure adequate supply. 


\section{Energy struggles as a source of citizen empowerment}

Among the propositions reviewed for this research was the suggestion that popular struggles around energy built on previous episodes of mobilisation around common concerns, and the presence of organisational leadership from groups with a history of such struggles. Pakistan's experience with contention around electricity confirms the proposition related to the demographic and sociological features of protestors. In the two field-sites chosen for in-depth investigation into electricity protests, Kamalia and Chungi Amer Sidhu (Lahore), research made it apparent that mobilisation was made possible by the preexisting presence of organisational infrastructure.

In the case of the working-class neighbourhood of Chungi Amer Sidhu, Lahore, the main organisational vehicle was a community-based organisation (CBO) called the Progressive Youth Front (PYF), formed by activists previously associated with labour unions in the nearby industrial cluster of Kot Lakhpat. The main organisers had also been affiliated with a local left wing political party and drew on their experience to set up a neighbourhood-based organisation. The activists also had political ambitions to compete in local government elections and saw the formation of a local CBO that dealt with service delivery complaints of residents as a way of cultivating a support base. Other members of the protesting public in this area included former women councillors who had served as local government representatives and had ties to politicians from both the PTI and the PMLN. Collectively, these organisers were supported by local shopkeepers and businesses who saw their ability to mobilise young people from the area as a useful way to place pressure on public authorities.

In the same vein, incidents of protests in the town of Kamalia, including the large-scale riot in June 2012, would not have attained the same scale and prominence without the considerable involvement of the market traders' association (Anjuman-e-Tajran Kamalia). As previously mentioned, traders constitute important public and political actors due to their financial, spatial, and status-based role in society. Their linkages with political parties, and in particular, the PMLN in Punjab, were instrumental in bringing large numbers of people on to the streets to protest against outages. This dynamic is important to mention in Pakistan's case - in the instances that we were able to track in detail, protests were organised and initiated by ostensibly non-partisan community-based actors (local businessmen, neighbourhood elites), however opposition political party activists and leaders would often become prominent participants as they progressed. It is thus reasonable to suggest that for these large-scale episodes 
of contention in Pakistan, the presence and working of political party leaders and activists was central to their escalation.

The research also proposed that popular mobilisation around energy was likely to feature mainly young urban men, and that such protests could as a result be inattentive to the needs of other social groups - women and children, rural people, the poorest - or for differing types of energy.

The findings from Pakistan significantly validates this proposition in multiple ways. For starters, cultural and socioeconomic constraints ensured that protest organisers were on many occasions better-off urban men, with protest participants often being working-class or lower middle class in nature. The protests against outages in Kamalia, for example, revealed that trader association representatives called for the protest, held the 'shutter-down' strike, and then ordered their shop employees (sales staff, loaders, and helpers) to block the main highway. The original group of protestors was then supplemented by local constituents of the opposition party politician who subsequently joined the protest.

In the case of Chungi, Lahore, numerous service delivery complaints - related to water shortages, electricity bill distortions and outages, and natural gas disruptions - actually originated from women residents of the neighbourhood, who had to deal with these more prominently due to the nature of domestic work. This finding is also echoed by other work on electricity in Pakistan which finds that women are the main electricity consumers at the household level, and therefore more directly affected by supply disruptions (Walker et al. 2016).

The question of what issues are taken up more prominently is one in which we see extensive variation due to gender and class dynamics. According to interviews with businessmen, government officials, and political representatives, one reason why public authorities prioritised generation enhancement and supply consistency is because outages impacted lives and livelihoods across different social classes. While home-based solutions to guard against outages (like fuel-run generators and uninterrupted power supplies) were widely adopted between 2007 and 2015, they remained costly and did not offer adequate substitutes, especially for commercial and industrial purposes. Hence the pressure imposed by elite, middle-class, and working-class actors on public authorities, both in the shape of public mobilisation, as well as extensive backdoor lobbying, was felt very strongly and accordingly dictated response.

On the other hand, the issue of affordability of electricity is one that politically impacts disempowered socioeconomic groups (fringe urban communities, rural consumers) more so than others. Even within these groups, there is a gendered dynamic on affordability given the way household labour is divided. Community interviews carried out with women respondents in Chungi showed that 
affordability issues remain a pressing concern, given household budget tradeoffs. Frequent overbilling, for example, is a persistent complaint, but one that most respondents have to live with in order to avoid disconnections or further surcharges.

Walker et al.'s (2016) analysis of household coping strategies to energy pricing echoes these findings. Both low-income and lower-middle-income households reported reducing spending on food to pay electricity bills. Katchi abadi (informal settlement) residents, Benazir Income Support Programme (BISP) beneficiaries and low-income households mentioned reducing the number of meals consumed and cutting out meat and other proteins. Lower-middle-income households, on the other hand, reported switching to lower-quality foods. Low-income households also reported cutting spending on childcare and education (e.g. sending children to public schools, and economising on school uniforms and equipment). Some respondents also reported reducing health expenses by avoiding doctor visits and using self-treatment.

In the same vein, in FGDs carried out in Chungi several respondents said that they had stopped purchasing meat because of both affordability concerns and because storing it in a refrigerator or a freezer meant incurring electricity costs.

These class and gender dynamics point to areas of concern around energy that do not impact public discourse and political events in the same manner that supply disruptions and outages have historically done in the preceding two decades. More data and research are required to better understand what coping strategies are utilised on issues of affordability and how they relate to citizen relations with public authorities.

We also explored the proposition that the experience of participating in or witnessing protests could create a sense of the potency of collective action. Interviews with protest participants in Kamalia and Chungi and with decisionmakers at the field level and the policy level point to mixed legacies of protest from an empowerment perspective. Protest organisers in Chungi were optimistic about the role that protests play; according to them, the fact that outages had reduced was directly the result of people coming out on the streets and holding public authorities to account. This view was also echoed by members of the Kamalia Traders' Association, who said that the ex-prime minister, Nawaz Sharif, paid attention to the demands of the public when he stepped into office in 2013, unlike Zardari (leader of the PPP), who ignored them.

At the same time, other protest participants were less enthused by the long-term impact of protests. They were reluctant to draw a direct connection between their presence on the streets and the eventual decisions taken by the government to improve generation capacity. Part of this is likely down to the insular nature of decision-making and the lack of institutionalised contact between voters, 
politicians, and those governing the energy sector in the country. Several respondents in Chungi also complained that even if the supply of electricity has gone up, their concerns about costs have never been paid attention to, and that local DISCO officials are quite rude and rarely attentive to their complaints about overbilling.

On the other hand, DISCO officials spoken to during the course of this research appeared very wary of prolonged supply outages given what they witnessed between 2007 and 2015. One DISCO official said that the threat to their lives posed by 'mobs' was extremely acute at that time and continues to condition the way they deal with outages and public anger. Another official said that DISCOs cannot afford prolonged outages because people are now aware that violent protests often work.

Politicians and other senior decision makers echo this in so far that they assert the political non-negotiability of electricity supply since the crisis. Given the important role played by electricity in shaping political outcomes in 2013, representatives from all mainstream parties, and particularly the two based in the largest province of Punjab - PTI and PMLN - acknowledge that an outage crisis, for whatever reason, can prove to be a political death knell. In one interview, a senior leader from the ex-ruling party involved with the electricity sector reform process stated that:

MNAs would visit Islamabad (the capital) and tell us they were afraid to go into their constituencies because of anger. Mian Mannan (MNA from Faisalabad) said he had a PhD in swear words and even he hadn't heard some of the abuse words he received during his visit to Sootar Mandi (yarn market in Faisalabad). This is the party's core support base and it had to respond to it someway.

Overall, the findings for this proposition echo the ones stated earlier, that while electricity supply has become an important political artefact given its crosssectional importance, affordability and associated service-delivery aspects are neither prioritised nor addressed in any meaningful way.

We explored the possibility that popular protest would dissipate when facing uninhibited state repression. We also sought evidence of empowerment that would include sustained campaigns or organisations pursuing the claims of the protests, or that protest groups or representative actors had played a substantive part in participatory and consultative processes over fuel price and social protection policies, including in setting the terms of such 'invited spaces'.

Closely related to the findings of the preceding proposition, and as expounded in the preceding section, is the fact that the architecture of energy governance in the country did not see any substantive change during and after the supply crisis. Decision-making continues to be done outside of representative oversight and in 
the absence of any inclusive channels. The legacy of contention has, so far, been absorbed into broader service delivery politics of mainstream parties through a centrality attached to ensuring supply but has not led to the formation of any civil society organisations that can articulate citizen voice on the issue.

However, the protest dissipation from 2015 onwards cannot be said to be a result of repression. It is more closely associated with the fact that the demand of those most influential within the protests has been met on an urgent basis by the state itself. The remaining concerns around affordability, for example, remain tied to populations under-represented in the political mainstream, and do not feature in the existing rent-driven incentive structure of elite actors. Similarly, the lack of emergence of any viable organisational form is closely tied to the underlying legacy of weak civil society activity in the country; much of what does exist is closely tied to the interests and agendas of international donor agencies. While more work is needed to establish this claim, it can be cautiously suggested that this gap is due to energy-related citizen empowerment not being central to the donor agenda in the country.

We further expected that state efforts to restrict civic and political space to prevent protests would disempower protestors committed to peaceful and legal means of contention, and that protests after a clampdown would be violent and deadly.

While the evidence presented here makes it clear that long-term empowerment on energy-related issues was not an outcome of contention in the country, it is also worth adding that the state did not specifically reduce the space for service delivery related protests, even while the crisis was ongoing. As already mentioned, violent police action was only witnessed in a small minority of cases, with protracted negotiations and political leverage often being deployed by municipal administrators to defuse protests.

Part of this can be traced back to the factors outlined earlier - the socioeconomic and political profile of those organising the contention, the contingent tensions between federal and provincial governments which reduced police deployment, and the shared sympathies between local administrations and protestors given the universal nature of the outage crisis. Therefore, we do not expect to see an escalation in violence based on a dynamic of restriction of civic and political space. 


\section{Transnational actors and the contentious political economy of energy}

The last aspect of this research explored whether and how countries with ongoing IMF austerity reforms were under pressure to cut downstream consumer fuel subsidies, and so were at greater risk of fuel price protests.

Since the global economic downturn of 2007, Pakistan has entered three separate IMF programmes $(2008,2013,2019)$ on the back of ballooning fiscal deficits and balance of payment crises, making it a good case to evaluate the link between structural adjustment programmes and energy-related contention. While subsidy removal (or rationalisation) was a key pillar of each programme, it was particularly prominent in 2008, which coincided with the uptick in electricity related contention (IMF 2007, 2009). However, the mechanism through which removal and protest are related is not as straightforward.

Subsidy removal in Pakistan's case was largely related to the TDS offered by the government to bridge the cost of generation and the cost faced by the endconsumer. The solution proposed repeatedly by the IMF, as well as the ADB and the World Bank, was regular increments in tariff to 'full-cost' recovery, to incorporate the overall increase in cost of generation posed by rising oil prices, and thus for the gradual removal of the TDS. Successive governments have been reluctant to comply with this fully, given the inflationary and politically sensitive impact of increases in the electricity tariff, which rendered the TDS necessary.

However, IMF programme fiscal deficit conditionalities also meant that governments were restricted in terms of the amount of resources they could spend on TDS to ensure sufficient generation was being carried out. In the absence of large fiscal outlays to cover the cost of fuel and generation, private sector electricity suppliers would stop producing, thus leading to outages (IMF 2013).

Overall, then, the IMF's advice for subsidy removal and tariff adjustment was indirectly linked to the outage crisis (and its ensuing protests) because it placed restrictions on the amount of money the government could spend to keep generation online, while keeping tariffs low. In both the 2008 and the 2013 programmes, upward adjustment of the electricity tariff to bring it closer to the cost of generation was a key conditionality, and one that governments, due to their obvious political implications, complied with only partially. It bears reiterating that equity analysis of the TDS with low consumer end tariffs, shows the biggest 
advantage of the subsidies being accrued to the richest category of consumers. This is demonstrated by the fact that after a major upward tariff adjustment undertaken by the government (on the IMF's insistence) the share of electricity subsidies for the richest 20 per cent of the population declined from nearly 40 per cent in March 2008 to 29 per cent in March 2011 (Trimble, Yoshida and Saqib 2011).

While it would be incorrect to suggest that IMF restrictions on government spending were completely responsible for generation reduction, given that the inability to spend more to curtail outages was also shaped by poor recoveries by some of the DISCOs, ${ }^{22}$ a stagnant economy, limited revenues, and exorbitant fuel prices, the IMF's conditionalities did play an important role in shaping the context that led to a period of significant electricity-related contention. However, it is worth mentioning that the uptake of IMF programmes is related to imprudent macroeconomic management, such as excessive fiscal deficits, some of which go to provide subsidies for expensively generated electricity.

The Pakistan case also lends itself to an evaluation of the extent to which international aid donors were sensitive to the political repercussions of popular protests around energy as were national elites, and alert to the political economy of fuel subsidy reforms.

IMF documents from 2007 onwards showcase a firm stance on the removal of 'distortionary subsidies' and an increase in electricity tariffs to improve macroeconomic stability (IMF 2009, 2013, 2017). Simultaneously, though, governments during this period were urged to spend more on direct social protection (such as BISP, the country's largest unconditional cash transfer programme) to ease the burden of higher tariffs and reduced subsidies (Bacon 2019).

The 2008-13 period, in particular, was one in which political repercussions weighed heavily on the federal government's decision-making, especially around tariff increases. As mentioned earlier, this was a time marked by slow economic growth and in which the ruling party, the PPP, had to rely on a range of coalition partners to secure a majority in parliament. The political space available to take unpopular inflationary decisions was extremely small, which meant that tariff increments were either delayed, or of a magnitude smaller than required to maintain the financial viability of the electricity supply chain.

As earlier work by Trimble et al. (2011) details, the government's notified tariff remained consistently below the cost-recovery tariff determined by the regulator,

22 The efficiency of DISCOs in collecting dues varies considerably. In 2018, the best had a domestic consumer recovery rate of 99 per cent, while the worst performing one had a recovery rate of 36 per cent. However, the tariff notified by the government is uniform for all of them (with variation in terms of consumer category, time of consumption, and level of total consumption), which essentially means that the high-performing DISCOs subsidise the poor-performing ones. 
NEPRA, during this time period. The increments that did take place were largely due to the conditionalities imposed by the stabilisation agreement with the IMF, as well as the technical assistance conditions attached to large-scale borrowing from the World Bank.

During interviews, officials from donor agencies tended to downplay their influence and role in the electricity sector. One senior representative of the World Bank, who had been involved in the reform process of 1994, pointed out that a way of assessing donor influence is to look at how many of the decisions have actually been implemented. Similarly, an IMF staff member based in Pakistan said that until 2013, reluctance to revise tariffs and make regular fuel price adjustments to meet the cost of generation, as advised by them, is indication of the political considerations from entrenched segments that public authorities remain mindful of, and shows the lack of influence donors actually have. ${ }^{23}$

While tensions between transnational actors and public authorities are prevalent in a range of country contexts, the role of the former in shaping the overall electricity sector in Pakistan cannot be understated. The primary reform process that led to privatisation of generation and a reduced role of the state on one end of the supply chain was conceived and led by the World Bank (Aziz and Ahmed 2015). ${ }^{24}$ Since the start of Pakistan's private electricity market in the late 1990s, the International Finance Corporation has made direct investments of over US\$850m in 19 projects (Zhang 2018).

The framing of what ails the electricity sector and what needs to be done to resolve it is also devised by transnational actors, as part of larger efforts to induce macroeconomic reforms. Across interviews with senior electricity sector officials and donors, privatisation of DISCOs and the creation of a competitive market in distribution were uniformly cited as the long-term solution. Similarly, the need to switch public conceptions of electricity away from being viewed as a right to a commodity - a long-standing transnational actor framing - was also echoed by respondents currently part of the federal government's taskforce on energy sector reform.

The relative homogeneity in the way the sector is understood and how responses are shaped can be traced back to the way that its governing architecture is set up. As mentioned in the earlier sections, the electricity sector

23 The indication here, and one that is borne out of the subsidy analysis, is that rather than social welfare considerations, it is the benefit accrued to richer consumers that governments are interested in protecting. fuel costs and variable operating and maintenance costs automatically pass through to determined generation tariffs, and plants receive a fixed capacity payment under long-term 'take or pay' contracts. It is now widely acknowledged that these terms were over-generous and have contributed to the financial ill-health of the entire sector. In interviews, World Bank staff maintain that these terms were necessary to mobilise investment in what is a particularly low-investment country context. 
is highly centralised with the federal government bureaucracy controlling almost all aspects of purchase, transmission and distribution. Political oversight is limited to the prime minister's office and the ministers for Finance and Energy (or Water and Power as the case was earlier), with preferential access given to powerful domestic business conglomerates (and increasingly Chinese companies) involved in electricity generation.

Given the country's bureaucratic structures and history of authoritarian rule, Parliament continues to have a negligible role in energy policy formulation, while civil society organisations working in this space are either absent or too weak to influence political discourse; at the same time, fiscal constraints and structural macroeconomic vulnerabilities that lead to periodic crises enhance the role played by lenders and donors in the country's political economy. It is within this environment that transnational actors and technocrats retain a privileged and considerably insular place in framing the debate around energy in Pakistan, one that has not changed much even after a prolonged period of crisis between 2007 and 2015.

We also proposed that external investment in energy infrastructure was likely to be highly contentious, particularly if human rights and due process were not observed in the planning process. Governments pushing through infrastructure and other economic development policies are likely to restrict space for civil society actors and the media to research or report on issues of energy investment and big projects.

China's increasing footprint on Pakistan's energy sector from 2013 onwards provides considerable evidence for this proposition. To date, 12 electricity generation projects, sponsored by Chinese loans and built/operated by Chinese companies, have either entered the construction phase or have begun their commercial operations. The total installed capacity of these projects is $7,240 \mathrm{MW}$ with an investment of about US\$12.4bn. A further US\$18bn is expected to be invested in an additional 12 projects up to 2025 (Andersen and Yang 2018).

As has previously been the case with private investments in generation, the terms offered to Chinese companies were not subject to substantial political oversight or deliberation. The government's own investigation into the financial health of the electricity sector revealed that in the case of two large coal power projects, Chinese investors asked for an unconditional acceptance of an up-front tariff, which was accepted by the regulator, NEPRA.

Similarly, land for the construction of one of the two coal-powered projects was purchased on behalf of the investor by the government through exercising the power of eminent domain in the agricultural district of Sahiwal. ${ }^{25}$ Concerns raised

25 In one account, a villager alleged that the government had threatened him with anti-terrorism charges if he refused to sell the land. 
by environmental and food security activists were repeatedly ignored, as the government cited national security and developmental ambitions as overriding factors. Overall, public authorities have repeatedly cited national security and geo-strategic factors as justifications for the lack of transparency and heightened centralised control around Chinese investment in the country (Boni and Adeney 2020). 


\section{Conclusions: Did energy struggles empower people to hold their rulers to account in Pakistan?}

What does Pakistan's experience with electricity related protests reveal? How did the 456 contentious incidents between 2007 and 2015 impact state-society relations, issues of empowerment and accountability, and more specifically, the nature of energy-related service provision?

\subsection{Fragility and contention in Pakistan}

Looking back at the key propositions developed for this research, a number of features from Pakistan's case provide both validation as well as nuance to the relationship between energy provision and contention in a context marked by fragility. Fragile countries are marked by low levels of trust and de-institutionalised relations between states and citizens, high degrees of economic instability, and various forms and axes of violent conflict. Pakistan's case demonstrates all three features to varying degrees.

More specifically, the electricity crisis was borne out of endemic macroeconomic vulnerabilities that made the country especially susceptible to shocks, such as the rapid increase in global oil prices from 2007 onwards. This coupled with fiscal constraints imposed by anaemic growth and a small revenue base for the state meant that there was little room to withstand and ease the consequences of an exogenous event of this nature.

Compounding this issue is the absence of institutionalised participatory channels for resolving complex policy and service-delivery questions, especially in an environment of adverse exogenous shocks. This fact - a trait in many countries with authoritarian legacies - is particularly relevant for Pakistan's energy sector, which remains managed by a narrow political and bureaucratic elite, driven by rent-seeking considerations. The lack of oversight, and the absence of functional accountability channels through representative forums such as parliamentary committees or consumer-centred citizen groups further prevent any meaningful reform on key issues of affordability and sustainability from taking place.

\subsection{The contingent possibility of accountability after contention}

The pervasive incidence of electricity-related contention in Pakistan between 2007 and 2015 offers key insights into what contextual and contingent factors 
make public authorities take action, especially in countries where programmatic and institutionalised pathways for accountability remain absent.

Principally, the case reveals that the role of geography, electoral incentives, protest participants, and timing of protests were extremely important in shaping how authorities eventually responded to the crisis in the electricity sector. In particular, the urgency of the response shown after the 2013 General Election, was made possible by the fact that some of the most violent protests (between 2010 and 2013) took place in the wealthiest and politically most salient region of North and Central Punjab.

This was further compounded by fact that from 2008 to 2013, different political parties governed the federal and Punjab governments (the PPP as federal government being responsible for the management of the electricity sector, and the PMLN as Punjab government being responsible for maintaining law and order) adding salience to the way the protests were perceived. PMLN leaders rode on an upswell in public anger by participating in local community-based protests, giving the resources needed to snowball small events into bigger episodes of contention. The local law and order apparatus, under control of the party, was asked to refrain from violent crackdowns on protestors, unless significant damage to public property was incurred. These factors allowed protests to achieve both 'voice' and 'teeth', shaping political discourse in a way that the incumbent federal tier ruling party, the PPP, was cast as principally responsible for the electricity shortages, and the 2013 General Election were considered as a single-issue referendum to establish the importance of resolving the crisis. This electoral pressure is what shaped the PMLN's eventual actions in office once it succeeded at the polls.

Another key aspect that enabled some form of action relates to the identity of the protestors and the groups most active in vocalising their discontentment. The protests were not just populated by political activists or workers but were planned and coordinated by sections of the urban business classes, in particular traders, merchants, shopkeepers, and other bazaar-based actors. Data from the events catalogue highlights that traders and associated businesses were the second most frequent segment involved in electricity related contention. Extant literature has already identified traders and associated businesses as a politically salient demographic, given their role in financing political activity at the constituency level and their status as local community leaders. Thus, parties in opposition during the 2008-13 period, such as the PMLN were quick to capitalise on public anger as it gave them a chance to demonstrate their representative credentials with key urban demographics. 


\subsection{The (im)possibility of empowerment}

While public authorities responded to the electricity shortage crisis by prioritising generation enhancement and ensuring consistent supply, its approach as a whole continued to echo older patterns of narrow, and exclusionary elite-led management of complex policy issues. The architecture of energy governance in the country did not see any substantive change during and after the supply crisis. Decision-making continues to be done outside of representative oversight and in the absence of any inclusive channels, while rent-seeking considerations remain prevalent in how major financial decisions are undertaken. The legacy of the period of contention between 2007 and 2015 was absorbed into broader 'service delivery politics' of mainstream parties with increased centrality accorded to the question of electricity supply, But it did not impact the way the sector was governed or managed as a whole in a way that could empower citizens and address key concerns around affordability and sustainability. Technocratic advice around marketisation and privatisation, dispensed by donors and local policy experts, drives the policy conversation, while structures of rent extraction, selective concessions, and political expediency dictate sector governance.

Part of this is down to the institutional legacy of elite-capture of policymaking and the political process as a whole. Pakistan's political parties remain beholden to elite interests and remain poorly institutionalised actors with little organisational links to marginalised groups in society. The absence of electoral channels of accountability with these marginalised groups, in contrast to responsive links with business elites and other upper-income segments, mean that there is little pressure 'from below' to change the way that policymaking and governance is carried out. Thus, the headline legacy of electricity-related contention is public authorities responding to immediate demands made by politically salient and powerful sections of the population, while ignoring the long-standing concerns of the poor and the marginalised. 


\section{Annexe 1}

\section{Figure A1 Protest distribution by month}

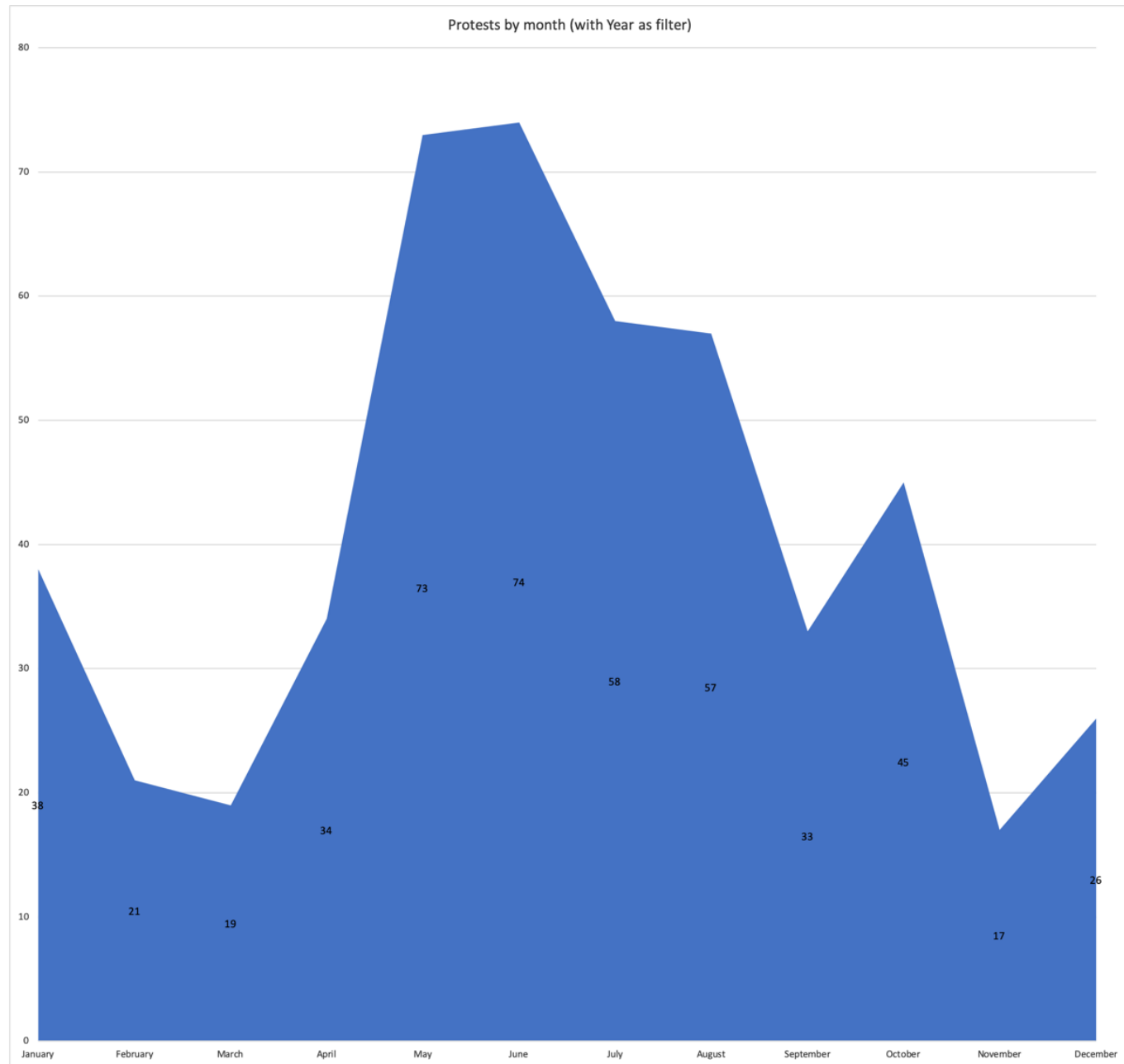

Source: Authors' own 


\section{Figure A2 Occupational profile of protestors}

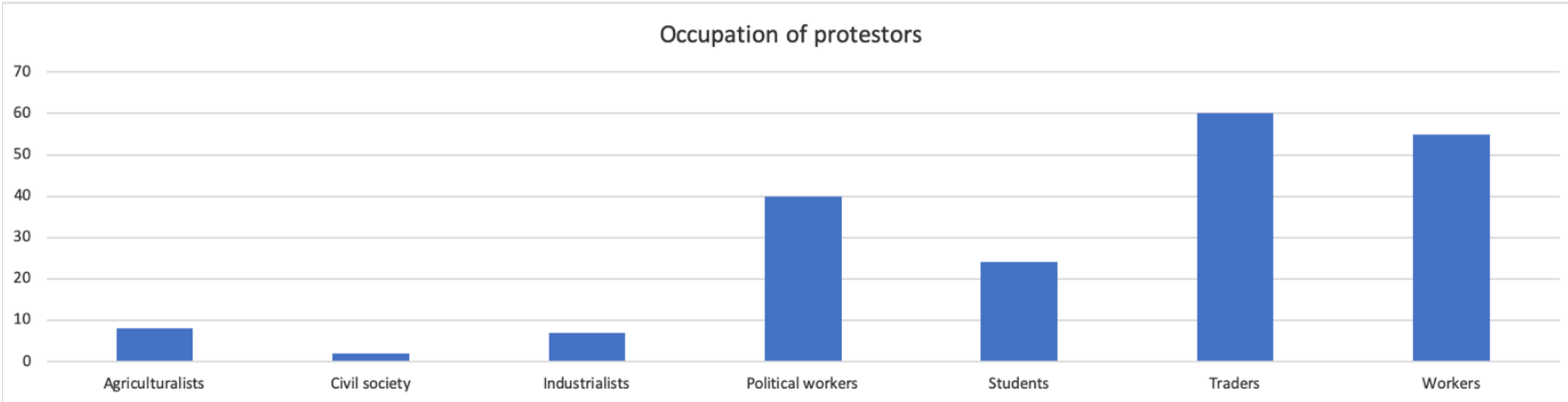

Source: Authors' own

\section{Figure A3 Frequency of violence in protests}

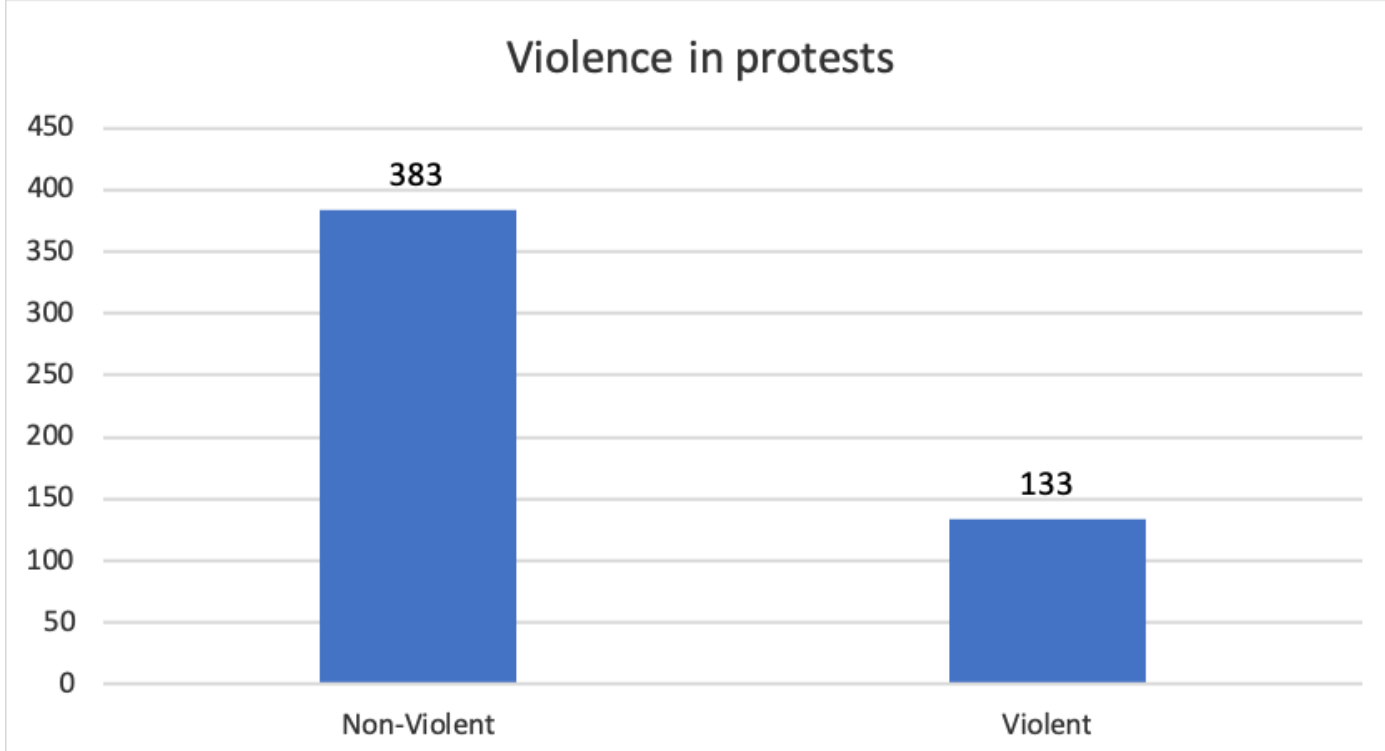

Source: Authors' own 


\section{References}

ADB (2020) Pakistan Reviving Growth through Competitiveness, Manila: Asian Development Bank (accessed 3 June 2021)

Akhtar, A.S. (2018) The Politics of Common Sense: State, Society and Culture in Pakistan, Cambridge: Cambridge University Press

Andersen, L.E. and Yang, J. (2018) Pakistan and the Belt and Road Initiative. China's Engagement in Pakistan, Afghanistan and Xinjiang: Will China's Root Cause Model Provide Regional Stability and Security?, Copenhagen: Danish Institute for International Studies

Asif, M. (2011) Energy Crisis in Pakistan: Origins, Challenges, and Sustainable Solutions, Karachi: Oxford University Press

Aziz, R. and Ahmad, M.B. (2015) Pakistan's Power Crisis: The Way Forward, Special Report 375, Washington DC: US Institute of Peace (accessed 20 April 2021)

Bacon, R.W. (2019) Learning from Power Sector Reform: The Case of Pakistan, World Bank Policy Research Working Paper 8842, Washington DC: World Bank (accessed 3 June 2021)

Boni, F. and Adeney, K. (2020) 'The Impact of the China-Pakistan Economic Corridor on Pakistan's Federal System: The Politics of the CPEC', Asian Survey 60.3: 441-65

Boone, J. (2012) 'Pakistan Power Cut Riots Spread as Politician's House Stormed', The Guardian, 19 June (accessed 17 January 2020)

Burki, S.J. (2007) 'The Weight of History: Pakistan's Energy Problem', in R.M. Hathaway, B. Muchhala and M. Kugelman (eds), Fuelling the Future: Meeting Pakistan's Needs in the 21st Century, Washington DC: Woodrow Wilson Center

Government of Pakistan (2020) Report on the Power Sector: Committee for Power Sector Audit, Circular Debt Resolution, and National Roadmap, Islambad: Government of Pakistan

Hossain, N. with Aremu, F. et al. (2018) Energy Protests in Fragile Settings: The Unruly Politics of Provisions in Egypt, Myanmar, Mozambique, Nigeria, Pakistan, and Zimbabwe, 2007-2017, IDS Working Paper 513, Brighton: Institute of Development Studies (accessed 20 April 2021)

IEA (2017) Energy Access Outlook 2017 From Poverty to Prosperity, World Energy Outlook Special Report, Paris: International Energy Agency

IMF (2017) Pakistan: 2017 Article IV Consultation-Press Release; Staff Report; Informational Annex; and Statement by the Executive Director for Pakistan, IMF Staff Country Reports 17/212

IMF (2013) Pakistan: 2013 Article IV Consultation and Request for an Extended Arrangement under the Extended Fund Facility, Washington DC: International Monetary Fund

IMF (2009) Pakistan: 2009 Article IV Consultation and First Review under the Stand-By Arrangement: Staff Report; Staff Statement; Public Information Notice and Press Release on the Executive Board Discussion; and Statement by the Executive Director for Pakistan, Washington DC: International Monetary Fund

IMF (2007) Pakistan: 2007 Article IV Consultation: Staff Report; Staff Statement; Public Information Notice on the Executive Board Discussion; and Statement by the Executive Director for Pakistan, Washington DC: International Monetary Fund

Javed, U. (2017) 'Profit, Protest and Power: Bazaar Politics in Urban Pakistan', in A. Pande (ed.), Routledge Handbook of Contemporary Pakistan, London: Routledge

Kiani, A. (2011) 'Impact of High Oil Prices on Pakistan's Economic Growth', International Journal of Business and Social Science 2.17: 209-16

Lodhi, A. Lf. (2017) Costing and Tariff Setting in Power Setting of Pakistan, Institute of Cost and Management Accountants of Pakistan (ICMA) Pakistan (accessed 27 April 2021)

Naqvi, I. (2017) 'Governance as an Emergent Compromise: Modernization and Flexibility in the Pakistani Electrical Power Sector', Current Sociology 65.2: 195-208

Naqvi, I. (2016) 'Pathologies of Development Practice: Higher Order Obstacles to Governance Reform in the Pakistani Electrical Power Sector', Journal of Development Studies 52.7: 950-64 
NEPRA (2020) State of Industry Report 2020, National Electric Power Regulatory Authority, Government of Pakistan

Trimble, C.; Yoshida, N. and Saqib, M. (2011) Rethinking Electricity Tariffs and Subsidies in Pakistan, Washington DC: World Bank

Walker, T.; Canpolat, E.; Khan, F.K. and Kryeziu, A. (2016) Residential Electricity Subsidies in Pakistan: Targeting, Welfare Impacts, and Options for Reform, Policy Research Working Paper 7912, Washington DC: World Bank

Zhang, F. (2018) In the Dark: How Much Do Power Sector Distortions Cost in South Asia?, Washington DC: World Bank 


\section{(2) institute of development \\ studies}

Delivering world-class research, learning and teaching that transforms the knowledge, action and leadership needed for more equitable and sustainable development globally.

Institute of Development Studies

Library Road

Brighton, BN1 9RE

United Kingdom

+44 (0)1273606261

ids.ac.uk

Charity Registration Number 306371

Charitable Company Number 877338

(C) Institute of Development Studies 2021 